\title{
Administrative Restrictions In The Field Of Business Activity
}

\section{${ }^{1}$ Selimanova Svetlana Mikhailovna, ${ }^{2}$ Ataev Shokir Quranboevich}

${ }^{1}$ Professor, Head of the Department of the Academy of the Ministry of Internal Affairs of the Republic of Uzbekistan, Doctor of Law, Uzbekistan.

${ }^{2}$ Senior Lecturer, Department of National Ideology, Fundamentals of Spirituality and Legal Education, Urgench State University, Uzbekistan.

\begin{abstract}
Administrative procedures in the field of entrepreneurial activity should be introduced in order to protect the rights and freedoms of citizens, property, ethics, public order and safety of citizens and the environment, and the effective organization of public administration in this area. The article analyzes the procedures for liberalization, licensing and permitting of administrative procedures in the field of entrepreneurship.
\end{abstract}

Keywords:

administrative-legal, realization, licensing, conceptual, business activities, sanitation, ecology, Oliy Majlis, Cabinet of Ministers. Article Received: 18 October 2020, Revised: 3 November 2020, Accepted: 24 December 2020

\section{Introduction}

As a realized form of administrative procedures is expressed in the permission of limited entities to carry out or perform the relevant activities. For example, licensed activities are granted only to entities that have completed the relevant licensing (administrative) procedures. The high level of administrative restrictions in the field of entrepreneurial activity not only stifles the freedom of economic activity, but also leads to clandestine economic activity. In particular, the high demand for limited performance results in the growth of this factor.

The administrative procedures in place in the field of entrepreneurship serve to "hold" the economy administratively and, more precisely, to further liberalize market relations, to hinder the development of private property and private entrepreneurship, rather than to regulate the economy. In this regard, E. Kanyazov rightly points out: "We believe that although the number of business permits has been significantly reduced, there are some activities that require a permit, which does not matter whether or not a permit is issued.». In particular, sanitary, ecological, urban planning norms and rules, fire safety rules, normative and technical requirements for standardization, as well as tax and financial procedures are inherently imperative and many procedures, which in the activities of any business entity violations of the norms can be observed. Also, these rules and norms were once adopted, uncomfortable formal requirements for the current scientific, technical and modern business environment. Because full compliance with these procedures leads to economic losses for the business entity, which, firstly, and secondly, most of these procedures are in fact, in fact, unnecessary or there is no real possibility to perform them on a regular basis. This allows public authorities, law enforcement and regulatory agencies to "break" a business entity at any time. As a result, business entities remain administratively and corruptly dependent on government agencies. In this regard, the President of the Republic Shavkat Mirziyoyev "At the same time, many entrepreneurs are in a position of true citizenship, providing unconditional support to orphans and vulnerable families, communities and social institutions.

What are they getting in return? The first is just the fear that they will start to check and squeeze again, the fear that they will no longer be able to work freely, to feed their family, their children. As a result, they are forced to "negotiate" with officials 
at various levels, even if there are no shortcomings or irregularities in their work.» it is worth mentioning that.

Excessive determination of the circumstances that require permission from public authorities to carry out certain actions in public life can lead to unfortunate situations. This, in turn, leads to a high risk of corruption, which ultimately threatens the constitutional rights and freedoms of citizens, the development of entrepreneurship, improving the investment climate in our country, the security of the individual, society and the state.

According to the results of surveys among business entities, fire safety, tax and state sanitary authorities are identified as bodies with imperative influence and other broad administrative powers. In particular, in a survey conducted among 750 business entities in cooperation with the Chamber of Commerce and Industry of the Republic, "Which of the following regulatory bodies worries you the most?" respondents to the question 97 (12.9\%) marked the answer as "fire safety authorities" and $196(26.1 \%)$ as "tax authorities". $168(22.4 \%)$ answered "state sanitary inspection bodies". Third, these norms impose on business entities (including business entities) obligations that are not actually necessary for performance. Therefore, it is necessary to conduct a full inventory of all administrative procedures in the field of entrepreneurship and introduce them in accordance with today's requirements.

In our opinion, the following norms and rules should be repealed: first, they represent obligations that are not realistic or impossible to fulfill; second, representing obligations that are not essentially necessary or whose performance would result in excessive costs; third, representing obligations that have a general meaning or can be interpreted broadly; fourth, it is corrupt and represents departmental interests.

When talking about the liberalization of administrative procedures in the field of entrepreneurship, it is necessary to pay special attention to licensing and permitting procedures. Because these procedures are "stony" and the most widely used public procedures in the field of entrepreneurship, the implementation of the basic economic rights of business entities is inextricably linked with these procedures. The Concept of Administrative Reforms in the Republic of Uzbekistan also includes the reduction of excessive administrative measures of state control (licensing and permitting procedures), the Action Strategy for the five priority areas of development of the Republic of Uzbekistan in 2017-2021. The state program for the implementation of the program also provides for the reduction and simplification of licensing and permitting procedures in the field of entrepreneurship.

In the literature, licensing and permitting procedures are recognized by the state as a method or means of legal regulation of the economy (including business activities). In particular, S.M. Selimanova describes licensing as an administrative-legal method of regulating legal relations.

In our opinion, in the liberalization of licensing and permitting procedures in the field of entrepreneurship, first of all, it is necessary to clarify the differences between these procedures and the reasons for their introduction. Permission and licensing are close, but not exactly the same thing. T.A. According to Cheryakova, the criteria for distinguishing between conceding (lat. Concedo - permitting, paving the way) and licensing are: the applicants; the legal status of the permitting entity; the method of objectifying his wish; the nature and extent of the legal capacity provided to the applicant; validity period. However, this view of the author allows only a mechanical distinction between permitting and licensing procedures from the outside and does not clarify the conceptual aspects of how these procedures differ from each other.

Although the licensing and permitting procedures in the national legislation of our country are defined by separate laws, the reasons for their introduction are determined on the same basis. This can be seen in the following table: 


\begin{tabular}{|l|l|l|}
\hline $\begin{array}{l}\text { Factors requiring permitting } \\
\text { procedures } \\
\text { Article } 4 \text { of the Law "On licensing } \\
\text { procedures in the field of entrepreneurial } \\
\text { activity") }\end{array}$ & $\begin{array}{l}\text { Factors requiring licensing } \\
\text { (Article 7 of the Law "On licensing of certain } \\
\text { activities") }\end{array}$ \\
\hline $\begin{array}{l}\text { Actions or activities, the implementation } \\
\text { or implementation of which may cause } \\
\text { harm to the rights and legitimate interests } \\
\text { of business entities, life and health of } \\
\text { citizens, public safety and the } \\
\text { environment }\end{array}$ & $\begin{array}{l}\text { Types of activities that may harm the rights } \\
\text { and legitimate interests of citizens, health, } \\
\text { public safety }\end{array}$ \\
\hline $\begin{array}{l}\text { Actions or activities that cannot be } \\
\text { performed by methods other than } \\
\text { regulatory authorization procedures }\end{array}$ & $\begin{array}{l}\text { Types of activities that cannot be regulated by } \\
\text { methods other than licensing }\end{array}$ \\
\hline
\end{tabular}

The lack of theoretical rules (theses) and legal framework that define the difference between permitting and licensing procedures, their specific features, also has a negative impact on the correct and reasonable definition of these procedures.

In general, the Law of the Republic of Uzbekistan "On Licensing of Certain Types of Activities", adopted on May 25, 2000, does not fully meet today's requirements. Because the norms of this law lag behind the relations in the context of reforms related to the deepening and liberalization of market relations in our country, and it can be said that in some places it hinders the effectiveness of these reforms.

In particular, Article 4 of the law provides for state regulation of licensing by the Cabinet of Ministers of the Republic of Uzbekistan and licensing bodies, but Article 7 of this law stipulates that the types of activities for which a license is required. Types of activities are determined in accordance with the Resolution of the Oliy Majlis of the Republic of Uzbekistan dated May 12, 2001 No 222-II "On the list of activities for which licenses are required." It is obvious that in addition to the Cabinet of Ministers and licensing bodies, the Oliy Majlis is also involved in the state regulation of licensing. After all, the regulation of licensing relations is, in essence, a functional task of the executive branch. Also, the decision of the Oliy Majlis to determine the types of activities for which licenses are required will have a negative impact on the liberalization of activities in this area. It is necessary to adopt the law of the Republic of Uzbekistan to cancel the relevant type of activity for which a license is required. The adoption of the law, on the other hand, consists of a number of specific stages, which require certain time and procedures.

In our opinion, the definition of the types of activities for which licenses are required for implementation should be transferred to the competence of the Cabinet of Ministers. In this case, first, as noted above, the implementation of licensing procedures will be at the discretion of the executive branch; second, licensing procedures will be further liberalized and the level of opportunities for its further liberalization will be increased. It should be noted that the list of licensing procedures in the field of entrepreneurial activity, as well as the licensing bodies for certain types of activities are also determined by the decision of the Cabinet of Ministers.

Article 8 of the law prohibits certain types of licensed activities from being carried out by individuals, but there are no criteria in which cases or which types of licenses are prohibited for individuals. In general, most of the types of activities that require a license to perform today cannot be performed by individuals. The conceptual basis for the introduction of licensing and permitting procedures is that the economic characteristics of the activities for which licensing 
or permitting procedures are envisaged are not a real case of endangering the external environment, but rather a consideration of possible circumstances.

In our opinion, the restriction between legal entities and individuals in licensing and permitting should be reasonable and fair. Otherwise, this situation will lead to the emergence of clandestine economic activity.

In the introduction of licensing and permitting procedures, the scientific and practical study of the specific conditions of the risk arising from the economic characteristics of the relevant activity, licensing and permitting procedures should not be disconnected from real life.

Another reason for the introduction of licensing and permitting procedures is the targeted regulation of relevant activities. This implies that the regulation of relevant activities cannot be regulated by methods other than licensing and permitting procedures.

What is meant by activities that cannot be regulated by methods other than licensing or permitting procedures? Which types of activities can be regulated by private-legal methods and which types of activities can be regulated by administrative-legal methods (licensing and permitting)?

The law sets out the grounds for suspension, revocation and termination of a license and a permit, but does not disclose the legal meaning of these sanctions. In addition, the basis for their use is not clearly defined. As a result, there are misunderstandings in the application of the above measures of influence in law enforcement practice.

Therefore, it is necessary to clearly define the concepts of suspension, revocation and termination of a license and a permit, as well as the grounds for their application.

Another promising priority for the liberalization of administrative procedures in the field of entrepreneurship is the state registration of business entities, the issuance of licenses and permits, as well as the widespread introduction of online forms of public services. This, firstly, by avoiding direct communication between the business entity and the state body (official) in the system of relations related to administrative procedures, saves the business entity from unnecessary time and expense, as well as relieves the hassle of going to the appropriate body, waiting in line, secondly, allows you to establish full control over the receipt, consideration and resolution of the application of the business entity related to the administrative procedure.

In this regard, it is necessary to provide opportunities for state registration, obtaining licenses and permits, reporting procedures via the Internet, the introduction of electronic queuing in the use of public services. Through our research, we have come to the conclusion that there are two main forms of economic liberalization. According to the first form, the relevant public-legal order is mechanically, that is, directly 'out of circulation', while according to the second form, the relevant procedures are conceptually liberalized. This is done by eliminating the factors that create administrative procedures.

The first form of liberalization immediately manifests its result, manifesting itself in the fact that the order that existed yesterday does not exist today. The second form of liberalization, while not immediately effective, is more effective and focuses on factors that imply the existence or existence of redundant administrative procedures and barriers.

\section{References}

[1] Kanyazov E. Simplification of licensing procedures in business // Theoretical and practical issues of further development of entrepreneurship and protection of private property: Proceedings of the Republican scientific-practical conference. - T., 2017. B. 12.

[2] Oqyulov O. A new stage in the development of the system of legal protection of entrepreneurs // Theoretical and practical issues of business development and further improvement of the system of protection of private property: 
Proceedings of the Republican scientificpractical conference. - T., 2017. - p. 15.

[3] Report of the President of the Republic of Uzbekistan Shavkat Mirziyoyev at the enlarged meeting of the Cabinet of Ministers on the main results of socioeconomic development of the country in 2016 and the most important priorities of the economic program for 2017 // Critical analysis, strict discipline and personal responsibility need // http://www. pressservice.uz.

[4] Kanyazov E. Simplification of licensing procedures in business // Theoretical and practical issues of further development of entrepreneurship and protection of private property: Proceedings of the Republican scientific-practical conference. - T., 2017. $446 \mathrm{p}$.

[5] Selimanova S.M. Administrative-legal sovershenstvovaniya litsenzionnoy sistemy v Respublike Uzbekistane: Avtoref. diss. ... Ph.D. jurid. science. - Tashkent, 2016. P.53.

[6] Gubin E.P. Legal problems of state regulation of market economy and entrepreneurship: Author. diss. ... Ph.D. jurid. science. - Moscow, 2005. - p. 14.

[7] Chervyakova T.A. Institute of licensing as an element of the development system: Avtoref. diss. ... cand. jurid. science. Minsk, 2010. - p. 13.

[8] Resolution of the Cabinet of Ministers of the Republic of Uzbekistan dated June 28, 2002 No 236 "On measures to implement the Law of the Republic of Uzbekistan" On licensing of certain activities "// National Database of Legislation of the Republic of Uzbekistan - http://lex.uz.

[9] Gurin A.I. Gosudarstvennyy kontrol kak forma osushchestvleniya ispolnitelnoy vlasti: Avtoref. diss. ... cand. jurid. science. - Moscow, 2005. - p. 7. 